\title{
Music and Testifying in Congregational Church: Faith Testimony (Marturia) in the Context of Church Music Festival at GMIM Territory
}

\author{
Alrik Lapian \\ Institut Agama Kristen Negeri Manado \\ alrik.lapian@yahoo.com
}

\begin{abstract}
Music in church is oriented not only in the fellowship of the congregation worship, but also in various events such as, concerts, festivals, and competitions. The problem occured is the meaning switching of the musical events. Music which is supposed to be a mean of testimony has become a mean of technical ability actualization. This problem lays on the competition mechanism which is emphasized on the aspect of performing technique and the event regulation. According to this issue, this study aims to reveal the function of music in church serving, in testimony area, especially at the Evangelist Church in Minahasa. The result of the analysis shows the theme of music as part of faith expression and music as the mean of testimony. This study is useful for the church musician to understand how the musical existance is supposed to be in the congregational especially at the Evangelist Church in Minahasa.
\end{abstract}

Keywords: Marturia, Church Musical Festival.

\section{Introduction}

The Christian Evangelical church in Minahasa (GMIM) is one of the churches based in North Sulawesi, a region which in there are many Christian monuments, Christian events, and lifestyles with Chritian's values. No wonder it is called "the Jerusalem of Indonesia". The GMIM existance in North Sulawesi is quite dominating. According to the Central Statistics Agency, $32 \%$ of the North Sulawesi province people are members of GMIM congregation [1]. Thus, it can be said that GMIM have a strong influence in forming spiritual identity in this region.

The orientation of GMIM service order basically lays on three aspects, namely: marturia (testifying), koinonia (fellowship) and diakonia (serving) [2]. From this three aspects, marturia seems to be the most fundamental thing of a church existance, either frthe quality aspect or from the quantity aspect. It is by testifying, people can be called for fellowship and be unable to serve [3]. In GMIM context, the awareness of the importance of marturia aspect in church service order has been well responded and has been quite inovative, for example by using musical media, by gathering the local composers to create songs according to the culture and tradition the congregation [4]. In addition, every church under the roof of GMIM is required to form a musical commision which is especially responsible to develop the musical development potential of each church member. Furthermore, GMIM also periodically hold various musical festival in all service group categories [5]. Hence, music has become an integral part in church service and a strategical tool in testifying (marturia).

By the time goes, music begins to spread over to the area of entertainment [6]. Modern culture encourage the birth of the market and the industrial development of religious music. 
For this reason, actress labeled as religious musicians appear, such as, Don Moen, Michael Smith, Darlene Zschech and Hilsong, Symphony music, True Worshipper,Jonathan Prawira, etc [7]. Many musicians choose this path to increase popularity and ignoring the testifying aspect (marturia) in their works since they have been influenced by the thing called by David willoughby as comersial popular music, Contemporary Christian Music and Gospel Rock [8].

The situation above seems starting to spread over the body of GMIM. Nowadays, the reality shows that GMIM often fail in facing the age movement and the demanding of global musicality development. It is at least seen from the existance of various church musical events held by GMIM which is emphazised on the performing technique and event regulations aspects more than the musical substance itself as the mean of faith testimony [9].

Based on this, does music still consider as the testimony milestone and the faith expression? or has it been swifted to self-actualization media of the participants, either for the organizers or for the musicians? This article aims to reduce the meaning switching of faith testimony through music by focusing on the implementation of church musical events held by the Evagelical Church in Minahasa. By this article, it is expected that the church can redefine music as faith expression and can shield itself from the rapid age movement.

\section{Discussion}

\subsection{Marturia}

The term of Marturia is derived from a Greek's word Martureo meaning witness or person who testify on something he witnessing. In the earlier church, the Greek word's Martus became limited, especially to call those who are loyal in their faith even though they have to die for it [10]. In Bahasa Indonesia, it is called martir [11]. In John: 21:24, Acts of Apostles $1: 22$ and 2 Peter 1:6, it is stated that the Apostles are the main witnesses of the life, death, and the ressurection of the Christ. Todays, marturia is usually used as the duty of church and the believers to tertify on Christ gift of love to the world [12].

The biblical basis of marturia is the Old Testament, known by the word witness, namely: witness in an agreement (Numbers 35:30, Leviticus 19:15), witness of an event (Leviticus:51, Numbers 23:18, Job 8:2). In the New Testament, HIS disciples are established as HIS witnesses (Luke 24:28, Act of Apostles 1:8). The duty of marturia in the church is simply to testify (a missionary) in the fellowship. The church duty as proclaimed by Jesus in the Great commission of Jesus Christ is to spread the Gospel (Mark 16:17, Matthew 28:20). Hence, there are three things need to be understood in testifying, which are: Who bear this testifying task? Definitely, it performs by all believers who has been called for being the gospel witnesses both for personal and community.

What is to be testified? It is the whole Gospel of Jesus Christ. Gospel is not about heaven and earth, nevertheless the emergence of Jesus to the world is to bring changes, which are, forgiveness, freedom, truth, and prosperity on HIS will.

Afterward, the purpose of the testimony must be clear which is surely all the human beings and the creatures (Mark 16:15). For this reason, church needs to clearly positioning itself as the administrator, the ruler, and the keeper of environment of this universe. A good gospel is not about the advance method of delivering but the way to love. By loving God, the love will overflow. By allowing Gods love fulfilling the life, the love will change one to be more meaningful for others. Being able to love others even the enemies, will make one understand their needs and their wishes. Moreover, one will be more understood the way to 
deliver the testimony of Jesus love and concern to this world, so that others are invited to take part in this love [13].

Currently, there are two ways of church testimony that we know, namely; First, internal testimony which means spreading gospel to guide and to grow the church and its members to be prepared for every good deed (2 Timothy 3:15-17), thus they are able to be the gospel witnesses in their environments and works. Second, external testimony is delivering gospel to all people and creatures in every aspects of their lives. In this case, church must be understood from prophetic function which is as the prophet responsible to present the Word of God.

Finally, gospel is not only about guiding to Christ but also about how the church follows Christ in a such a way so that everyone who choose to follow Christ will feel accepted and appreciated. Thus, the gospel is not about how to bring it to the world, but how we together with others find the presence of God in the world.

\subsection{The Aspect of Marturia in Music}

Music is an inseparable part of the Christians life, because through music the faith appreciation can be expressed [14]. Various events are recorded in the Bible, and music always becomes a benchmark in the relation of God and His people, at once as the central point in appreciating life experience with God. This appreciation then gives birth to the faith testimony of Gods people themselves.

Exodus 15:1-21 records how Moses and all the people of Israel give their faith testimony through music about the art of God salvation on them from the enemy at once elevating the Gods attributes [15]. In addition, the verse implicitly describes how music enable articulating the relationships of God and His people.

The other event in the Bible involving music as the tool of faith testimony is the ordination of the wall of Jerusalem in Nehemiah 12:27-43. The music played creates difficulties and it is heard farther or in other words it brings huge effects and victory to every ears listening to it. Beside these two events, another Bible passage including marturia aspect in music is the book of Psalm. This book with 150 chapters obviously describes various types of faith expression of the writer, starting from dissapointment, complaining, complaint, regret, sadnesss, loneliness, fear, worries, wasted, happiness, cheerfulness. Additionaly, the Bible also mentions some figures in it who testifying their faith through music, such as: song of Moses (Exodus 15:219); song of Miream (Exodus 15:20-21); songs of Debora and Barak ( Judges 5:2-3); the gratitude song of Hana (1 Samuel 2:1-10); the gratitude songs of David (2 Samuel 22); the song of Marie (Luke 1:46-55), the song of Zechariah (Luke: 1:68-79); the song of angels (Luke 2:14); the song of Simon (Luke 2:29), the song sang by Lord Jesus (Matthew 26:30) and the songs of Paul and Silas (Acts. 16:25) [16].

According to the testimony from the Bible above, it is obvious that the faith development of the people is often expressed with music because music full of theological meaning which becomes a testifying reference (marturia) [17]. With music, people can praise, worship, pray and proclaim Gods deeds and blessings experienced in life. Thus, between music and marturia, there is a tight affiliation. Each music played has to posses tertimony aspect (marturia) within. Moreover, musical service is not more or less than but a church duty which is serving God, serving His people, and also serving the world [18]. It means that the aims of musical service are not for entertainment, for fulfilling the musical style of the priest, or for preserving the culture and tradition but merely for praising and glorifying God as well for being able assisting the congregation to the presence of God. Consequently, music should have the characteristics as follows: 
a) Being spiritual in nature that is able to be a communication media with the transcendent or containing spirituality as the manifestation of soul worship [19].

b) Sourced from the Bible or inspiring by the Word of God as the main message (soul).

c) Creating liturgical nuance or worship. In this context, worship is interpreted as people respond to the Gods calls who has saved humans from the shackles of sin, so that people can be together offering gratitude, praise, and worship.

d) Assisting people to the presence of God. This means that the music performed can create joy, freedom, peace and prosperous atmosphere. With music, people can be changed, from the ways of thinking, acting, and absorbing each grace performed by God [20].

\subsection{Church Music Festival in GMIM Territory}

The enforcement of the church music festival in the territory of GMIM has been a regular agenda. Evidently, in last few years, it is often held. The whole support both from the regency/city government and from the provincial government also succeed this event. Furthermore, the implementation of this event is considered as a unifying media and an effort to dissociate young generation from the promiscuity which can threaten their future, beside being a tool for increasing musicality of the congregation members and for channeling interest and talents.

The church music festival implementation can draw attention of the public, not only for the GMIM members but also for the society. So that, it often causes traffic at some points where the event carried out. The same attention is also showed by most GMIM members in welcoming this festival. A lot of congregations compete in its preparation, from budgeting to technical preparation by doing regular practices, presenting competent coaches even buying song which is considered having a high level of dificulties. Everything is done to get the best result and prestige among the church members. Furthermore, the committee also mobilize all aspects and abilities to present a competent competition which is highly competitive.

In 2019, this event is joined at least by around 500 participants which is devided into several competition criteria starting from choirs (6 categories), vocal group (3 categories), vocal star and plays. Furthermore, the foundation of this event is Bible as the Word of God, GMIM church order of 2016, hearing decision of synod assembly, commission work program, GMIM synod decree. The purposes of this event are increasing the church calls sourced from the mandate and example of Jesus Christ in spreading Gods Word in the Bible as the salvation news; developing potential and talents to glorify the greatness of Gods name; situating the church members in the national and state life which is caring for others and environment as Gods creation; increasing faith, togetherness and strengthening the sense of unity and oneness of the church members. Moreover, for the assessment category, GMIM has standards including; majority, intonation, intensity, voice colour, voice accuracy and maturity, attack and release, rhytm and time, balance, breathing, wording, tempo, dynamics, revealing interpretation, tidiness, reasonable attitude, harmony, orderly, public mastering, discipline, etc [21].

Behind the event which seems luxurious, exclusive, and sacred, a question arises. Can this event become a tool of faith testimony? Or does it only become an indication of church situation which has fallen into the spirit of new age which according to Wilfred J. Samuel, it tends to be celebrative [22].

To answer this question, the writer reviews three main elements namely, the musicians, the audience and the material or the songs performed. At first, the musicians are those assigned to perform the song, including, the singer, the instrumental players and the conductor. The 
musicians are supposed to be the people who has given themselves up as the tool of testimony. Therefore, they have to live in holy and posses skills in this field so that they are able to transform the faith value through music. Nevertheless, a different situation is found on the musicians performing at the church music festival. Many of them before performing often consume alcohol drinks until they are half drunk. It is done to overcome the nervous feeling when performing on stage. Concerning the capacity, there are lots of musicians having no skill in music. For them, this event is merely a fulfillment of the congregation work program and a hobby even some performing for money [23].

Second, the audience is all the present congregation members for listening to the faith testimony of the musicians or in other words the audience is the object of the testimony itself. Consequently, one of the things closely related to the audience is that they must have a longing to be in the presence of God and a sensitivity in appreciating each tone played. It is upside down with what happened at the church music festival held by GMIM. The audience often do not understand the meaning behind the music played. They are impressed by the luxury of music, the rhytm and the pitch of the singers voice without experiencing spiritual touch. The audience make music as the main object of a show. They forget that basically music is a tool or a media to reac God. It is surely directly shows that church music festival only emphasizes on ceremonial aspect and it has no spiritual effect.

Third, the material or the music substance being played. From the musical aspect, the song performed has a high difficulty level and is often used in international events. Such of song preference is reasonable seeing from the high assesment standard established by the committee. However, behind its luxury and beauty, the music performed again do not show any aspect of marturia within. As a reference, one of the songs performed by a participant is Ave Maria by Ivan Yohan. This song indeed has a deep meaning about marialogy or introduction of Maria as God servant and an appreciation to the women. Nevertheless, it loses its theological meaning when the people listening to it do not understand the meaning of the song. It is the fact found in the church music festival that the lack of knowledge and sensitivity of the musicians and the audience on the music performed results in the music which is supposed to be a tool of testimony (marturia) switching to be ceremonial. For this reason, church music festival which is supposed to be full of praising, worshiping, and introduction to God has been a talent show and an entertainment stage.

\section{Conclusion}

From the discussion above, it can be concluded that the church music festival held by the Evangelical Church in Minahasa has experienced meaning switching. If at the beginning, this event is meant to be a testifying media and a faith expression of the congregation, now it has changed to be a talent show and a competition to be the best. Therefore, no wonder if the marturia aspect is now rarely found in the church music festival. It is obviously indicated from the three main elements of the festival, namely; the musician, the audience, and the material being performed. Thus, all of us especially the academia and the church musician have to pay attention more on the marturia aspect. So that, the music performed have a meaning and an impact to everyone hearing. Lastly, let the name of God always praised and glorified. 


\section{References}

[1] The Central Bureau of Statistics (BPS) data in 2017 said that the number of population in North Sulawesi is 2.461 .028 and the 795.809 of them $(32,3 \%)$ are members of GMIM. See Bidang Informasi dan Data BPMS GMIM at www.gmim.or.id

[2] As a member of Council of Churches in Indonesia (CCI), the service order of GMIM is basically found on three aspects, namely; marturia, koinoniaanddiakonia. These are called the Three Mission of Church.

[3] The same thing applied to the early church, they were formed from testimony (marturia) of the Apostle about the gospel of Christ. Bdk. Acts 2:14-40.

[4] The concept is agree with the thought of David R. Ray about the authentic worship. He emphasizes the importance of the church to present contextualization in worship so that the people can appreciate their faith more. See Ray David R.: Gereja yang Hidup. BPK Gunung Mulia. p. 41 (2000)

[5] See Tata Gereja GMIM Pasal II Bab IX Peraturan tentang Komisi Kerja dan Panitia, in www.gmim.or.id

[6] Jackson,Jerma A.:Singing in my soul black gospel music in secular age. Chapel Hill. pp. 103-130 (2004)

[7] Hardjana,Suka: Corat-coret musik kontemporer dulu dan kini. Ford Foundation and Masyarakat Seni Pertunjukan Indonesia. p. 257 (2003)

[8] Willoughby,David.:The world of musik 3rd edition.Brown \& Benchmark Publiser. p. 53 (1996)

[9] The church music festival of GMIM is merely to rise the euphoria atmosphere and it is less effective for the glory of God. The same critique said by a church musician expert, John F. Wilson, that the music performed by the church is nothing but to arose the emotion of the congregation members. See Wilson Jhon F.:An intorduction to church musik. Moody Press. p.18 (1965)

[10] Bosch,David J. translated by Stephen Suleeman:Transformasi misi kristen: sejarah teologi misi yang mengubah dan berubah. BPK Gunung Mulia. p. 77(2006)

[11] Yewangoe,A.A.:Tidak ada penumpang gelap: warga gereja, warga bangsa. BPK Gunung Mulia. p.39(2009)

[12] Milne,Bruce: Mengenali Kebenaran.BPK Gunung Mulia. p.312 (2002)

[13] Singgih Emanuel Gerrit:Berteologi dalam konteks: Pemikiran-pemikiran mengenai kontekstualisasi teologi di Indonesia. Kanisius. p.212 (2000)

[14] Boschman Lamar:Exploring the mysteries of worship. worshipinstitute. p. 3 (2005)

[15] Selvaraj,Sadhu Sundar:Seni menyembah menjadi penyembah yang dicari tuhan. Nabiri Gabrie. pp. 41-44 (1996)

[16] Osbeck,W.:The ministry of music. Kregel Publication. pp. 17-23 (1985)

[17] Mawene:Gereja yang bernyanyi. ANDI. p. 1 (2007)

[18] Leafblead,Bruce: Music and worship. Baptist Theological Seminary. pp. 5-7 (1999)

[19] Kendrick,Graham: Pujian dan penyembahan. Mimery Press. p. 83 (1984)

[20] Berlund,Robert:A philosophy of crurch music. Library of Congress. pp. 5-7 (1985)

[21] The assessment form (the judging system) used by GMIM seems referring to what is used at the international music festival. Bdk. https://bandungchoral.com/bicf8. Thus, it can be said that the standard of the competition established by GMIM is equal to the international one.

[22] Samuel,Wilfred J.: Kristen Karismatik. BPK Gunung mulia.p. 68 (2007)

[23] Marinis,Marco de.:The semiotics of performance. Indiana University Press. pp. 21-33 (1993) 